\title{
Perancangan Dan Implementasi Supply Chain Management (SCM) Pada CV Hayati Padang Silfia Andini, ${ }^{1}$, Lukas Pratiknyo ${ }^{2}$ \\ ${ }^{12}$ Universitas Putra Indonesia
}

\begin{abstract}
ABSTRAK
Manajemen rantai pasok adalah suatu sistem pada suatu organisasi itu menyalurkan barang produksi dan jasanya kepada para pelanggannya. Dari sudut struktural, sebuah supply chain management merujuk kepada jaringan yang rumit dari hubungan dimana organisasi mempertahankan dengan partner bisnis untuk memperoleh bahan baku, produksi dan menyampaikannya kepada konsumen. Manajemen rantai pasok bagi CV HAYATI yang mengelola distribusi dan penjualan, sangat membantu dalam pemenuhan kebutuhan konsumen, meningkatkan volume penjualan produk sehingga memberikan nilai positif bagi perusahaan.Berdasarkan penelitian yang dilakukan secara langsung ke lapangan dengan metode observasi, serta mempelajari literature yang berhubungan dengan masalah yang dibahas, diharapkan sistem yang baru ini dapat meningkatkan kualitas informasi sehingga bermanfaat bagi instansi yang bersangkutan.
\end{abstract}

Kata Kunci : Supply Chain Manajemen (SCM), CV.HAYATI, Website, Distribusi.

\section{PENDAHULUAN Latar Belakang}

Persaingan di dunia bisnis dan perkembangan teknologi informasi yang cepat, menuntut perusahaan untuk melakukan perubahan dalam proses bisnis, dari proses bisnis yang manual ke proses bisnis yang terkomputerisasi untuk meningkatkan efektifitas dan efisiensi bisnis yang ada dan untuk menjawab tantangan-tantangan dari kemajuan teknologi informasi.

CV Hayati merupakan perusahaan yang bergerak di bidang bisnis penjualan sepeda motor merk Honda, CV Hayati berstatus sebagai main dealer (dealer utama) untuk wilayah Sumatera Barat. Aktifitas perusahaan sehari-hari meliputi penjualan sepeda motor, spare part, dan perawatan.

CV Hayati sering mengalami masalah keterlambatan dalam pemenuhan permintaan konsumen, baik di dealer pusat maupun di dealer cabang. Hal ini dikarenakan kurangnya informasi tentang ketersediaan produk sehingga perencanaan dan penjadwalan distribusi baik dari pusat ke main dealer ataupun dari main dealer ke dealer cabang sering terjadi keterlambatan.
Akibatnya banyak permintaan konsumen yang tidak dapat terpenuhi tepat waktu, sehingga konsumen sering kecewa atau harus memesan dan menunggu hasil pemesanan dalam waktu yang cukup lama. Hal ini akan sangat berpengaruh pada kredibilitas dan turunnya image perusahaan dimata konsumen. Oleh karena itu diperlukan supply chain management (SCM) untuk membantu mengatasi masalah tersebut.

\section{Perumusan Masalah}

Berdasarkan latar belakang di atas, penulis merumuskan masalah sebagai berikut:

1. Bagaimana otomatisasi informasi melalui penerapan supply chain management dapat membantu $\mathrm{CV}$ Hayati memenuhi permintaan konsumen?

2. Bagamana penerapan Supply Chain Management dapat membantu $\mathrm{CV}$ Hayati mampu meningkatkan volume penjualan? 


\section{Hipotesis}

Berdasarkan perumusan masalah di atas dapat dibangun hipotesa sebagai berikut:

1. Dengan perancangan supply chain management diharapkan mampu untuk memenuhi permintaan konsumen sehingga mampu menjaga kredibilitas perusahaan dimata konsumen.

2. Dengan perancangan supply chain management diharapkan mampu meningkatkan volume penjualan pada CV Hayati.

\section{Tujuan Penelitian}

Tujuan ingin dicapai dalam penelitian Tugas Akhir ini adalah :

1. Mengetahui Proses supply chain management Perusahaan.

2. Merancang aplikasi untuk membantu perusahaan dalam melakukan supply chain management.

\section{LANDASAN TEORI \\ Rekayasa Perangkat Lunak}

Istilah Rekayasa Perangkat Lunak (RPL) secara umum disepakati sebagai terjemahan dari istilah Software engineering. Istilah Software Engineering mulai dipopulerkan pada tahun 1968 pada software engineering Conference yang diselenggarakan oleh NATO. Sebagian orang mengartikan RPL hanya sebatas pada bagaimana membuat program komputer. Padahal ada perbedaan yang mendasar antara perangkat lunak (software) dan program komputer.

Perangkat lunak adalah seluruh perintah yang digunakan untuk memproses informasi. Perangkat lunak dapat berupa program atau prosedur. Program adalah kumpulan perintah yang dimengerti oleh komputer sedangkan prosedur adalah perintah yang dibutuhkan oleh pengguna dalam memproses informasi (O’Brien, 1999).

Pengertian RPL sendiri adalah suatu disiplin ilmu yang membahas semua aspek produksi perangkat lunak, mulai dari tahap awal yaitu analisa kebutuhan pengguna, menentukan spesifikasi dari kebutuhan pengguna, disain, pengkodean, pengujian sampai pemeliharaan sistem setelah digunakan (Aunur Rofiq Mulyanto, 2008).

Dari pernyataan diatas dapat disimpulkan bahwa Rekayasa perangkat lunak tidak hanya berhubungan dengan cara pembuatan program komputer. Pernyataan "semua aspek produksi" pada pengertian di atas, mempunyai arti semua hal yang berhubungan dengan proses produksi seperti manajemen proyek, penentuan personil, anggaran biaya, metode, jadwal, kualitas sampai dengan pelatihan pengguna merupakan bagian dari RPL.

\section{Unified Modeling Language}

Unified Modelling Language (UML) adalah sebuah "bahasa" yang telah menjadi standar dalam industri untuk visualisasi, merancang dan mendokumentasikan system piranti lunak (Sulistiyorini,2009).

\section{Supply Chain Management}

Supply chain (rantai pengadaan) adalah suatu sistem pada suatu organisasi itu menyalurkan barang produksi dan jasanya kepada para pelanggannya (Indrajit dan Djokopranoto,2003).

Konsep supply chain adalah juga konsep baru dalam melihat persoalan logistik. Konsep lama melihat logistik lebih sebagai persoalan intern masing-masing perusahaan dan pemecahannya dititik beratkan pada pemecahan secara intern di perusahaan masing-masing. Dalam konsep baru ini, masalah logistik dilihat sebagai masalah yang lebih luas yang terbentang sangat panjang sejak dari bahan dasar sampai barang jadi yang dipakai konsumen akhir yang merupakan mata rantai penyediaan barang.

Supply chain management adalah seperangkat pendekatan digunakan untuk mengintegrasikan pemasok, produsen, gudang, dan toko-toko, sehingga barang yang diproduksi dan didistribusikan pada jumlah yang tepat, ke lokasi yang tepat, pada waktu yang tepat, untuk meminimalkan biaya sistem yang luas sehingga memuaskan pelayanan tingkat kebutuhan (David Simchi-Levi). 
Supply chain management adalah sebuah proses dimana produk diciptakan dan disampaikan kepada konsumen. Dari sudut struktural, sebuah supply chain management merujuk kepada jaringan yang rumit dari hubungan dimana organisasi mempertahankan dengan partner bisnis untuk memperoleh bahan baku, produksi dan menyampaikannya kepada konsumen (Kalakota, 2001, p274).

Menurut (Indrajit dan Djokopranoto,2003), ada beberapa pemain utama yang mempunyai kepentingan yang sama di dalam supply chain management yaitu:
a. Suppliers
b. Manufacturer
c. Distribution
d. retail outlets
e. customers

\section{METODOLOGI PENELITIAN}

\section{Penelitian Pendahuluan.}

Penelitian pendahuluan merupakan tahap yang penting dalam sebuah penelitian. Melalui penelitian pendahuluan kita bias mendapatkan informasi awal yang menguatkan asumsi-asumsi dan memberikan bukti awal bahwa masalah yang akan kita teliti di lapangan benarbenar ada.

Langkah-langkah yang dilakukan penulis dalam penelitian pendahuluan adalah :

1. Memahami masalah yang menjadi fokus dalam penelitian.

2. Mengajukan perizinan kepada CV Hayati sebagai objek penelitian.

3. Mencari informasi tentang masalahmasalah yang terjadi dilapangan yang berhubungan dengan topik penelitian.

\section{Pengumpulan data atau Observasi}

Dalam melakukan pengumpulan data penulis meminta data dengan cara survei langsung kelapangan untuk mengambil data yang diperlukan dan melakukan wawancara terhadap staf-staf yang bekerja di CV Hayati.

\section{a. Waktu penelitian}

Adapun penelitian ini dilakukan pada periode Oktober - November 2012.

\section{b. Tempat Penelitian}

Objek penelitian yang lakukan penulis adalah CV Hayati Padang yang beralamat di Jalan Pemuda no 11A Padang.

\section{c. Metode Penelitian}

Dalam pengumpulan data dan informasi untuk penulisan laporan studi akhir ini penulis melakukan beberapa cara, yaitu :

1. Penelitian Lapangan (FieldResearch), yaitu penelitian yang dilakukan untuk mendapatkan data primer secara langsung pada subjek penelitian dengan cara melakukan pengamatan dan wawancara dengan pihak yang berkepentingan di perusahaan tersebut.

2. Penelitian Pustaka(Library Research), penelitian yang dilakukan untuk mendapatkan data sekunder dengan cara membaca dan mempelajari literatur- literatur yang berhubungan dengan permasalahan.

3. Penelitian laboratorium (Laboratory research), merupakan tahap penelitian yang dilakukan dengan cara research labor komputer guna mempraktekkan langsung hasil dari analisa yang bertujuan untuk menguji kebenaan sistem yang dirancang. Adapun hardware dan software yang digunakan dalam penelitian laboratorium ini yakni dengan spesifikasi antaralain :
a. Perangkat keras (Hardware)
1) Motherboard Intel
2) Processor Intel Core TM $15-2410 \mathrm{M}$ CPU @ 2.30 GHZ (4 CPU s)
3) Harddisk $500 \mathrm{~GB}$
4) Memori 2 GB
5) VGA Intel® HD Graphics Family
b. Perangkat Lunak (Software) 
1) Sistem operasi Microsoft windows 7 home premium

2) Microsoft Office 2007

3) Notepad ++

4) Macromedia Dreamweaver 8.0

5) easyWAM / XAMPP 1.7.7

6) Google Chrome

7) Rational rose

8) E-Draw dan software pendukung lainnya

\section{ANALISA DAN PERANCANGAN}

\section{Analisa Sistem}

Analisa sistem merupakan tahap awal dalam perancangan dan pengembangan sebuah sistem yang akan dirancang, karena pada tahap inilah akan diukur dan dievaluasi kinerja dari sistem yang dirancang, identifikasi terhadap masalahmasalah yang ada dan langkah-langkah untuk kebutuhan perancangan yang diharapkan. Dalam melakukan analisis sistem terlebih dahulu harus mengetahui dan memahami sistem, untuk menganalisa sistem diperlukan data dari sistem untuk dianalisa.

\subsection{Prosedur Sistem yang Sedang Berjalan}

Setelah melakukan penelitian langsung untuk melihat sistem yang berjalan pada CV Hayati Padang, penulis menemukan masalah yaitu sering terjadi keterlambatan dalam pemenuhan kebutuhan konsumen terutama pada dealer-dealer cabang CV Hayati. Hal ini terjadi karena sistem yang berjalan sekarang dinilai kurang efisien, adapun sistem yang berjalan sekarang adalah sebagai berikut :

1. Dalam peran CV Hayati sebagai distributor sepeda motor area Sumatera Barat, pemesanan barang dari dealer cabang ke CV Hayati masih menggunakan cara manual, yaitu dengan menggunakan telepon.

2. Pemesanan dari CV Hayati ke Astra Honda Motor sebagai supplier telah menggunakan program yang diberi oleh Astra Honda Motor, dari program tersebut menghasilkan file dalam bentuk *.txt kemudian file tersebutlah yang dikirimkan ke Astra Honda Motor untuk melakukan pemesanan. Setelah diterima oleh pihak Astra Honda Motor kemudian file tersebut diimport lagi kedalam software yang sama sehingga isi pesannya dapat dibaca.

\section{Perancangan Sistem}

Setelah dilakukan analisa, maka untuk tahap berikutnya adalah melakukan perancangan sistem. Perancangan sistem dilakukan sebelum melakukan coding. Tahap ini bertujuan untuk memberikan gambaran apa yang seharusnya dikerjakan dan bagaimana tampilannya. Tahap ini membantu dalam menspesifikasikan kebutuhan hardware dan sistem serta mendefinisikan arsitektur sistem secara keseluruhan.

\section{Pembuatan Use Case Diagram}

Use case diagram adalah deskipsi fungsi dari sebuah sistem dari perspektif pengguna. Use case bekerja dengan cara mendeskripsikan tipikal interaksi antara user (pengguna) sebuah sistem dengan sistemya sendiri melalui sebuah cerita bagaimana sebuah sistem dipakai. Pada Use Case Diagram aktor pengguna dihadapkan dengan beberapa fitur menu yang dapat digunakan, dan disini terdapat 5 aktor yaitu, admin, petugas, cabang dan supplier.

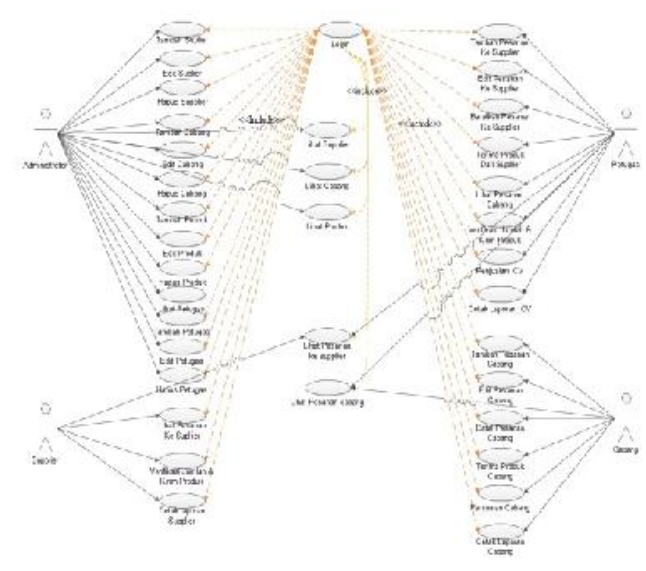

Gambar1.Use Case Diagram 


\section{Class Diagaram}

Class Diagram menggambarkan keadaan (atribut atau properti) suatu sistem, sekaligus menawarkan layanan untuk memanipulasi keadaan tersebut (metoda atau fungsi).

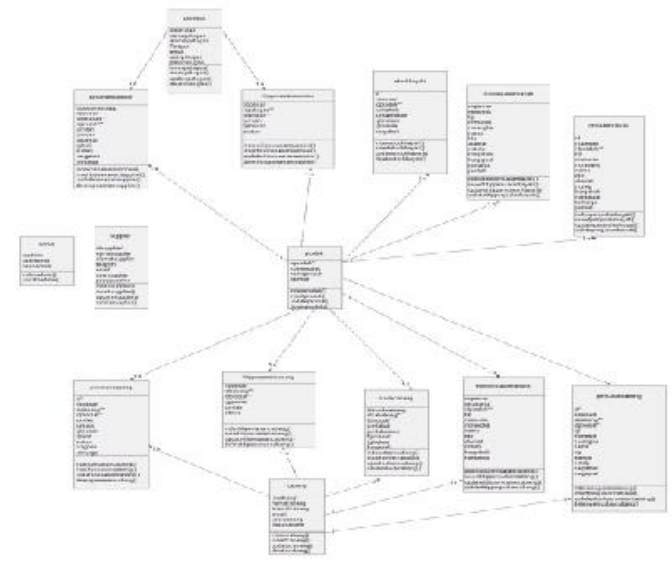

Gambar 2. Class Diagram

\section{Sequence Diagram}

Sequence diagram menggambarkan interaksi antar objek di dalam dan di sekitar sistem berupa message yang digambarkan terhadap waktu. Sequence diagram terdiri antar dimensi vertikal (waktu) dan dimensi horizontal (objek-objek yang terkait)

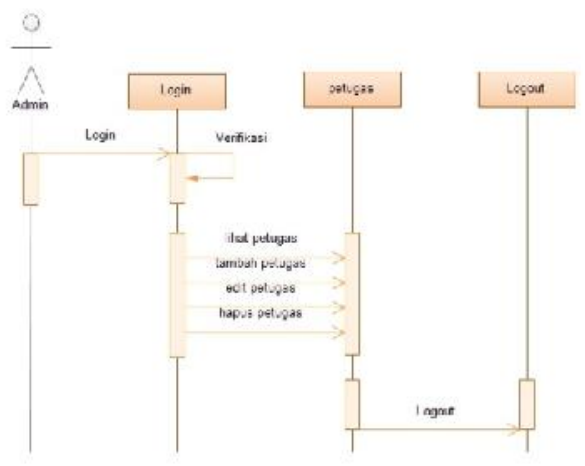

Gambar 3. Sequence diagram manajemen petugas

\section{Collaboration Diagram}

Collaboration diagram merupakan cara alternatif untuk menampilkan suatu scenario. Menampilkan interaksi obyek yang terorganisasi di sekitar obyek dan hubungannya dengan obyek yang lain.

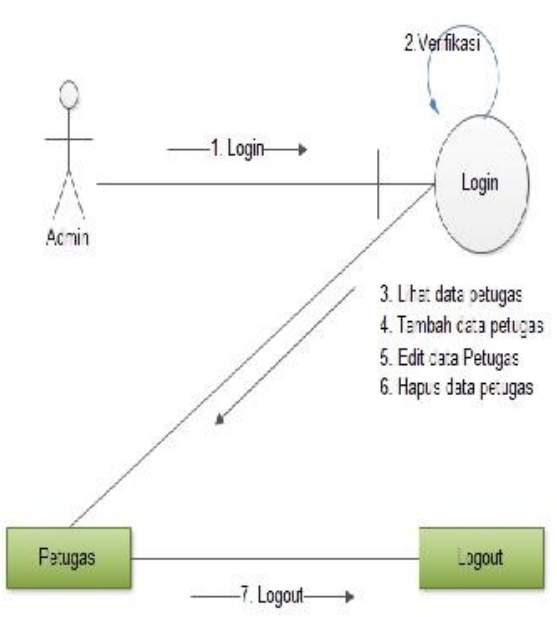

Gambar 4 Collaboration diagram manajemen data petugas

\section{State Chart Diagram}

State Chart Diagram berfungsi untuk membantu analis, perancang dan pengembang untuk mamahami perilaku objek dalam system.

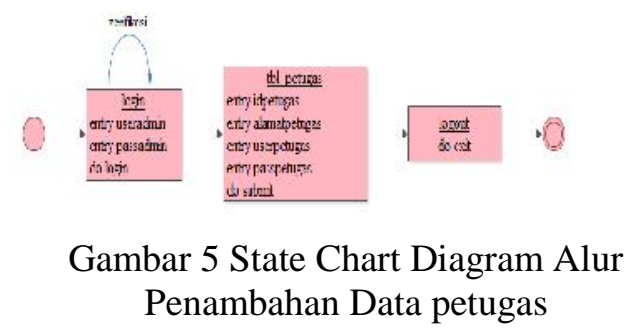

\section{Activity Diagram}

Activity diagram menggambarkan berbagai alir aktivitas dalam sistem yang sedang dirancang, bagaimana masing-masing alir berawal bagaimana mereka berakhir. 


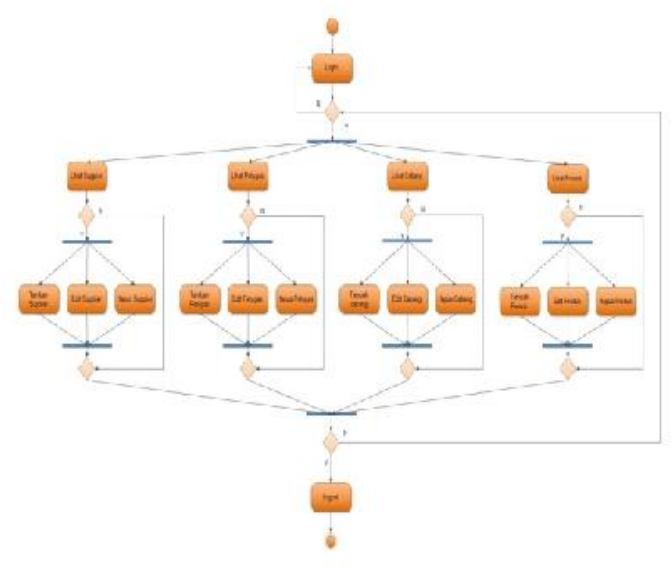

Gambar 6. Activity Diagram Administrator

\section{Deployment Diagram}

Deployment diagram menunjukkan tata letak sebuah sistem secara fisik, menampakkan bagian-bagian software yang berjalan pada bagian-bagian hardware. Deployment/physical diagram menggambarkan detail bagaimana komponen di-deploy dalam infrastruktur sistem, di mana komponen akan terletak (pada mesin, server atau piranti keras apa), bagaimana kemampuan jaringan pada lokasi tersebut, spesifikasi server, dan halhal lain yang bersifat fisikal.

\section{IMPLEMENTASI DAN PENGUJIAN Implementasi Program}

Untuk mengimplementasikan program aplikasi yang telah dirancang, maka diperlukan sebuah alat bantu berupa komputer, yang mana untuk mengoperasikan komputer itu sendiri memerlukan tiga buah komponen pendukung seperti hardware, software, dan brainware. Untuk lebih jelas dapat dijelaskan fungsi dari masing-masing komponen sebagai berikut :

\section{Hardware}

Perangkat keras (hardware) merupakan sebagai pendukung operasi pengolahan data yang digunakan untuk merancang atau menjalankan program yang telah dibuat.

2. Software

Perangkat lunak (software) adalah perangkat abstrak yang merupakan bagian utama selain hardware dari sistem komputer. Untuk menjalankan program yang dirancang perlu software pedukung untuk menjalankan program tersebut.

Salah

satunyasoftware EasyWAMP

v1.1.EasyWAMP v1.1 merupakan salah satu aplikasi server lokal, didalam software AppServ itu tersendiri sudah termasuk apache, php, MySQL, dan phpMyAdmin sebagai tempat penampungan database.

\section{Brainware}

Brainware meupakan operator yang berfungsi untuk mengoprasikan atau menjalankan program. Jadi ketiga komponen diatas memiliki fungsi jika digunakan bersama-sama dengan software, sedangkan brainware adalah orang yang akan mengoperasikan program, tanpa brainware komputer tidak akan bisa beroperasi.

\section{User Interface}

Berikut ini adalah hasil printscreen dari program perancangan dan implementasi supply chain management pada CV Hayati Padang

1. Tampilan Halaman Login

Halaman ini digunakan untuk proses login user sebelum dapat mengakses berbagai macam menu yang tersedia sesuai dengan hak akses dengan cara memasukkan username, kemudian pilih level dan masukkan password..

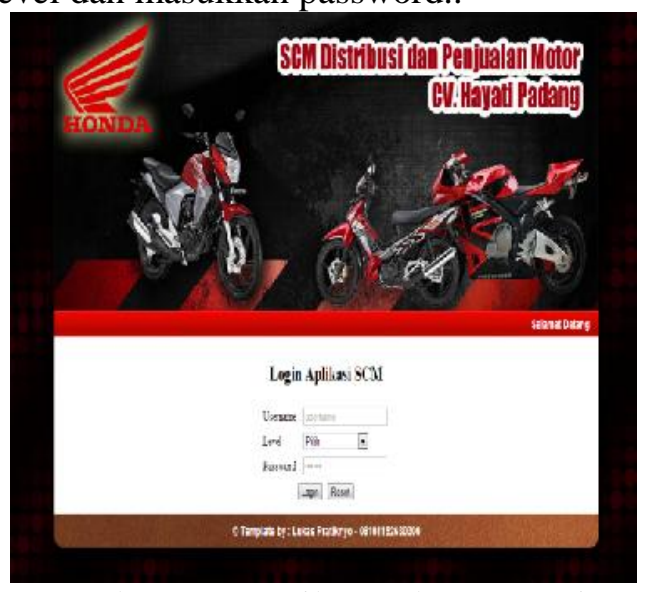

Gambar 7. Tampilan Halaman Login

23 Diterbitkan Oleh Program Studi Pendidikan Informatika STKIP PGRI Sumbar 
2. Tampilan Halaman Admin

Halaman ini merupakan halaman utama ketika admin baru saja berhasil login.

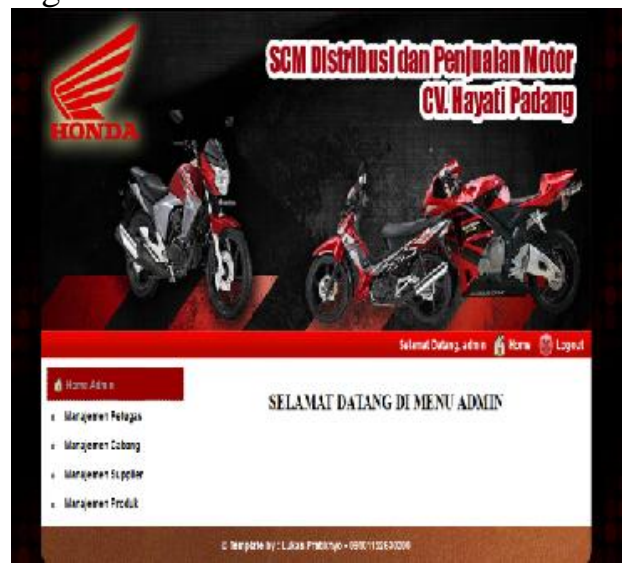

Gambar 8. Halaman Admin

3. Tampilan Halaman Manajemen Produk

Halaman ini digunakan oleh admin untuk melihat data produk, dengan cara klik manajemen produk. Didalam halaman ini terdapat tombol tambah produk, edit produk dan hapus produk.

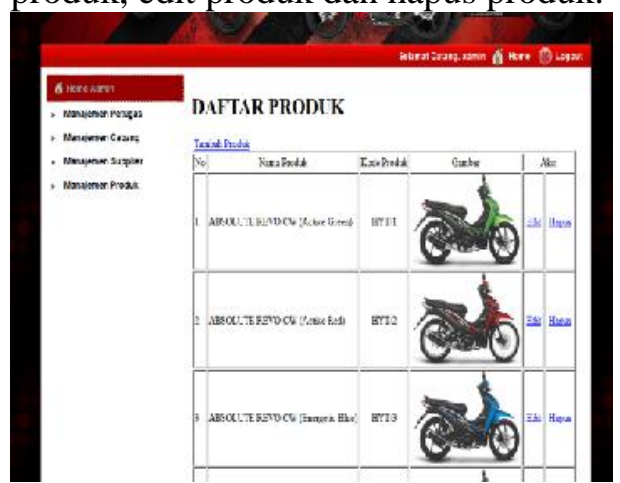

Gambar 9. Halaman Manajemen Produk

4. Tampilan Halaman Tambah Produk

Halaman ini digunakan oleh admin untuk menambah data produk, dengan cara klik manajemen produk, kemudian isikan data produk, dan simpan.

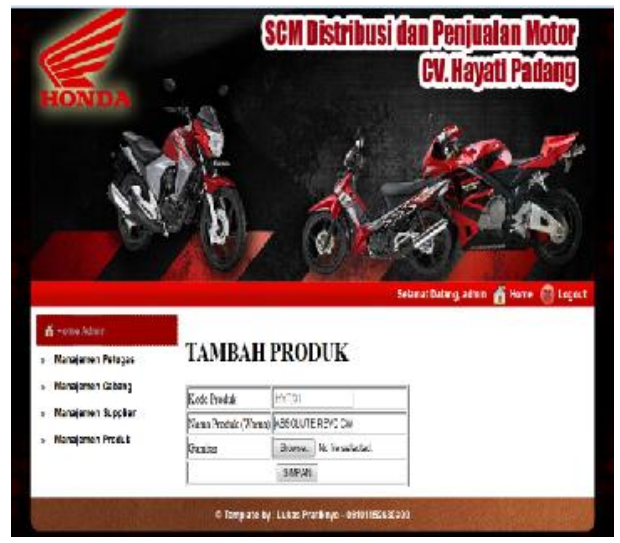

Gambar 10 Halaman Tambah Produk

5. Tampilan Halaman Edit Produk.

Halaman ini digunakan oleh admin untuk mengedit data produk, dengan cara klik manajemen produk, lakukan pengeditan data produk dan simpan.

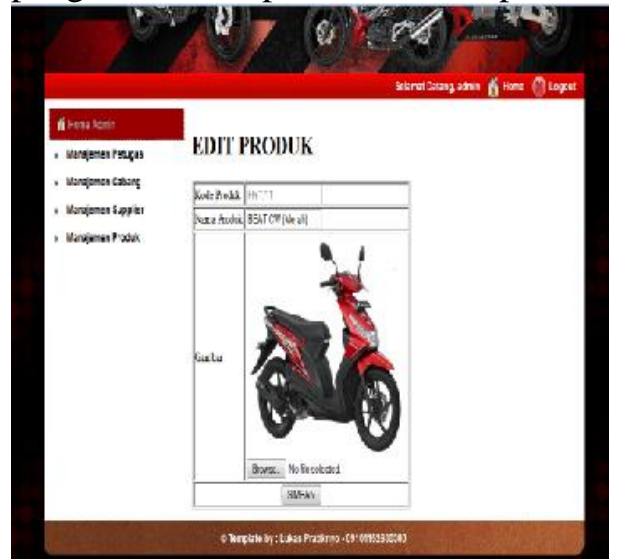

Gambar 11. Halaman Edit Produk

6. Tampilan Halaman Petugas.

Halaman petugas merupakan halaman home petugas pada saat petugas berhasil login.

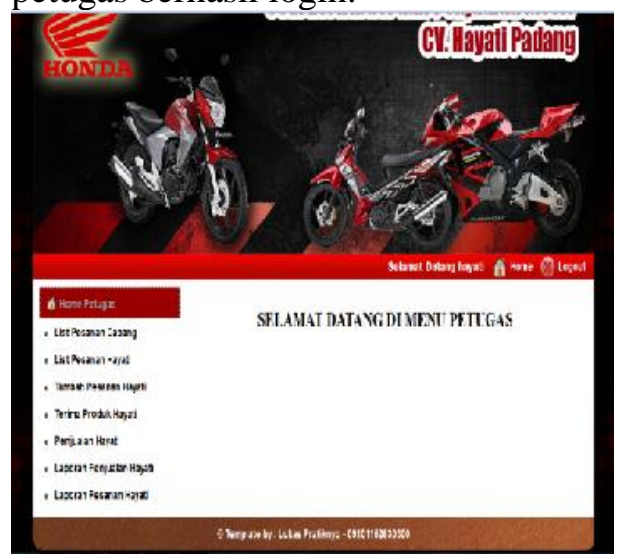

Gambar 12. Halaman Petugas 
Penelitian Bidang Komputer Sains dan Pendidikan Informatika

7. Tampilan Halaman List Pesanan Cabang Oleh Petugas.

Halaman ini digunakan oleh petugas untuk melihat data pesanan cabang, data pesanan cabang dapat dilihat berdasarkan tanggal dan berdasarkan pesanan yang belum diproses dengan cara klik list pesanan cabang.

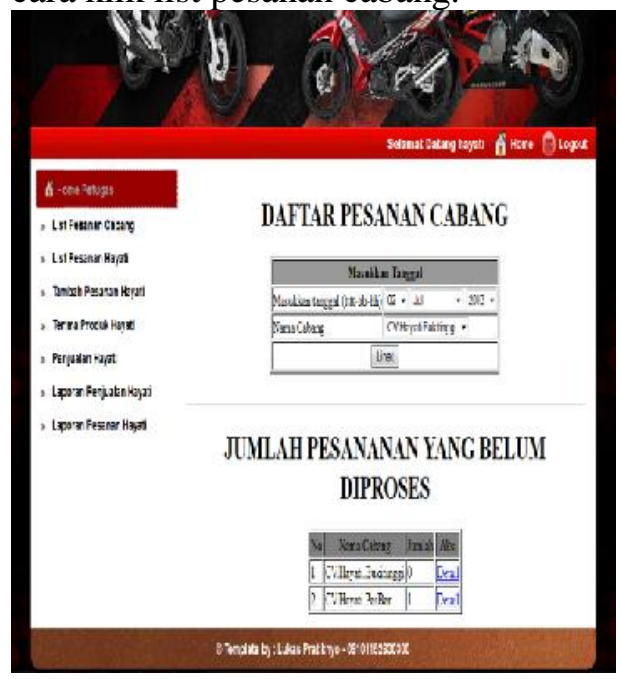

Gambar 12. Halaman List Pesanan Cabang Oleh Petugas

8. Tampilan Halaman Tambah Pesanan Hayati

Halaman ini digunakan oleh petugas untuk menambah pesanan hayati, dengan cara klik tambah pesanan hayati, pilih produk, kemudian isikan jumlah dan simpan, setelah selesai semua klik simpan.

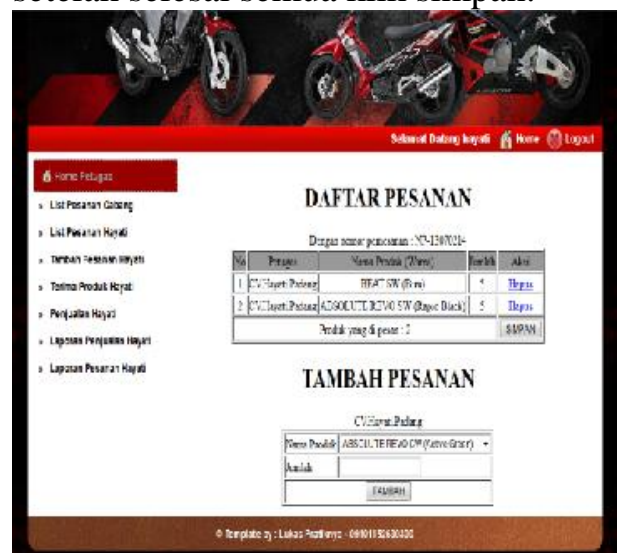

Gambar 13. Halaman Tambah Pesanan Hayati
9. Tampilan Halaman Penjualan Hayati

Halaman ini digunakan oleh petugas untuk melakukan penjualan produk pada $\mathrm{CV}$ hayati secara langsung kepada konsumen.

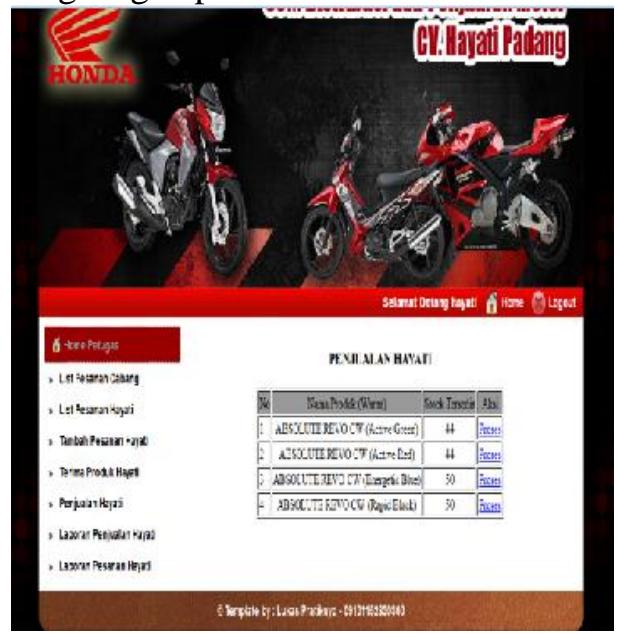

Gambar 14. Halaman Penjualan Hayati

10. Cetak Laporan Transaksi Penjualan

Halaman ini merupakan halaman yang digunakan petugas untuk mencetak laporan transaksi penjualan petugas, yaitu dengan cara klik laporan penjualan hayati, kemudian masukkan tanggal, kemudian pilih harian atau bulanan, kemudian isikan nama penanggung jawab, dan klik cetak.

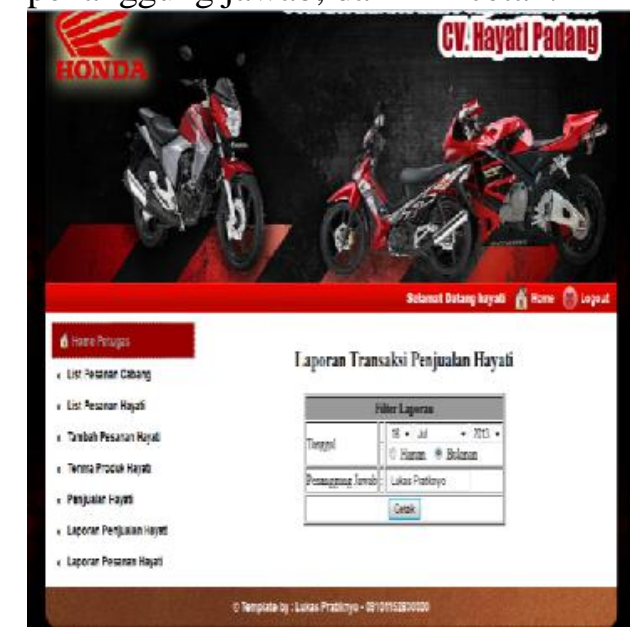

Gambar 15. Halaman Cetak Transaksi Penjualan Hayati

\section{KESIMPULAN}

Dari penelitian yang telah dilakukan maka dengan menerapkan konsep supply chain managemen pada CV Hayati Padang 
dapat diambil kesimpulan sebagai berikut, yaitu:

1. Dengan adanya sistem supply chain management ini $\mathrm{CV}$ hayati dapat mengendalikan stok sepeda motor sehingga permintaan konsumen dapat terpenuhi. Sebelumnya produk yang ingin dibeli konsumen sering kosong namun setelah adanya aplikasi $S C M$ ini stok produk dikendalikan secara terkomputerisasi sehingga petugas dapat mengetahui jika stok produk hampir habis sehingga petugas dapat segera memesan produk kepada supplier untuk menghindari kekosongan stok.

2. Dengan sistem $S C M$ ini perusahaan dapat mengendalikan pemesanan dan distribusi sepeda motor baik dari supplier ke CV Hayati maupun dari CV hayati ke cabang sehingga semua permintaan konsumen dapat terpenuhi dan tentunya akan meningkatkan volume penjualan CV Hayati.

\section{DAFTAR PUSTAKA}

Abdullah, Syahrul Mubarak . Rancang Bangun Pusat Informasi Narkotik Dan Obat-Obatan Terlarang (Narkoba) Berbasis WEB. Jurnal ILKOM, 1-10, (2010).

Binanto, Iwan. konsep bahasa pemrograman.Andi, Yogyakarta, (2006).

Fathansyah. Basis Data. Informatika, bandung, (2004).

Indrajit, Richardus Eko dan Djokopranoto. Konsep Manajemen Supply Chain Strategi Mengelola Manajemen Rantai Pasokan Bagi Perusahaan Modern di Indonesia, PT Gramedia Widiasarana Indonesia, Jakarta, (2003).

Kadir, Abdul. Dasar pemrograman web dinamis menggunakan PHP - Edisi revisi. Andi, Yogyakarta, (2008).

Komputer, Wahana. Menjadi Seorang Desainer WEB. Andi, Yogyakarta, (2005).
Mulyanto, Aunur R. Rekayasa Perangkat Lunak Jilid I. Departemen Pendidikan Nasional, Jakarta, (2009).

Munawar. Pemodelan Visual dengan UML. Graha Ilmu, Yogyakarta, (2005).

Pujawan, I Nyoman. Supply Chain Management, Edisi Pertama. Guna Widya,Surabaya, (2005).

Sanjaya, Ridwan. pengolahan database mysql 5 dengan java 2 disertai teknik pencetakan laporan. Andi, Yogyakarta. (2005).

Simarmata, Janer. Rekayasa Perangkat Lunak. Andi, Yogyakarta. (2010).

Sulistyorini, Prastuti. Pemodelan Visual dengan Menggunakan UML dan Rational Rose. Jurnal Teknologi Informasi XIV, 23 - 29. (2009).

Widodo, Prabowo Pudjo dan Herlawati. Menggunakan UML .Informatika, Bandung, (2011). 